\title{
PENDIDIKAN KESEHATAN TENTANG PNEUMONIA BERBASIS MTBS TERHADAP PENGETAHUAN IBU DI PUSKESMAS WILAYAH CILACAP SELATAN I
}

\author{
HEALTH EDUCATION ABOUT MTBS-BASED PNEUMONIA \\ TOWARD MOTHER'S KNOWLEDGE IN AREA PUBLIC HEALTH \\ CILACAP SELATAN I
}

\author{
Ahmad Subandi, Ida Ariani2 \\ Prodi D3 Keperawatan, STIKES Al Irsyad Al IslamiyyahCilacap \\ STIKES Al Irsyad Al Islamiyyah, Cilacap, Indonesia
}

Email:ahmadsubandi19@yahoo.com

\begin{abstract}
INFO ARTIKEL ABSTRAK/ABSTRACT

Kata Kunci : Pendidikan Kesehatan, Pneumonia, Pengetahuan

Key Word :

Health

Education, MTBS, Knowledge

Anak merupakan tunas, potensi, serta generasi muda sebagai penerus bangsa yang mempunyai peran strategis dan ciri atau sifat khusus yang menjamin kelangsungan sebuah bangsa dan Negara. Di Indonesia berdasarkan hasil Riset Kesehatan Dasar (Riskesdas) tahun 2018, peneumonia merupakan penyebab tertinggi kematian pada bayi dibawah lima tahun maupun bayi baru lahir, menunjukkan; prevalensi nasional pneumonia naik dari $1,6 \%$ pada tahun 2013 menjadi $2 \%$ populasi balita di Indonesia.WHO merekomendasikan untuk melaksanakan program MTBS yang diadaptasikan sesuai dengan permasalahan kesehatan bayi dan balita di Indonesia. Pendidikan kesehatan merupakan serangkaian upaya yang ditujukan untuk mempengaruhi orang lain, mulai dari individu, kelompok, keluarga dan masyarakat agar tatalaksanya perilaku hidup sehat. Hasil penelitian menunjukkan tingkat pengetahuan sebelum dilakukan pendidikan kesehatan sebanyak $10(33,3 \%)$ sedangkan tingkat pengetahuan sesudah dilakukan pendidikan kesehatan sebanyak $20(66,7 \%)$ dengan nilai $\mathrm{Pv}=0,01<0,05$.

Children are budding, potential, and the young generation as the successor to the nation who have a strategic role and special characteristics or traits that guarantee the survival of a nation and state. In Indonesia based on the results of the Basic Health Research (Riskesdas) in 2018, peneumonia is the highest cause of death in infants under five years old and newborns, showing; the national prevalence of pneumonia rose from $1.6 \%$ in 2013 to $2 \%$ of the under-fives population in Indonesia. WHO recommends implementing the IMCI program that is adapted to the health problems of infants and toddlers in Indonesia.Health education is a series of efforts aimed at influencing others, ranging from individuals, groups, families and communities so that the management of healthy behavior. The results showed the level of knowledge before health education was 10 (33.3\%) while the level of knowledge after health education was 20 (66.7\%) with a value of $P v=0.01$ $<0.05$
\end{abstract}




\section{A. PENDAHULUAN}

Anak merupakan tunas, potensi, serta generasi muda sebagai penerus bangsa yang mempunyai peran strategis dan ciri atau sifat khusus yang menjamin kelangsungan sebuah bangsa dan Negara (Djamil, 2013). Anak juga merupakan kekayaan yang paling berharga yang menentukan masa depan suatu bangsa. Sehingga, menjaga dan memelihara kelangsungan hidup dapat menentukan masa depan bangsa dimasa mendatang (Fida dan Maya, 2012). Anak juga merupakan kekayaan yang paling berharga yang menentukan masa depan suatu bangsa. Sehingga, menjaga dan memelihara kelangsungan hidup dapat menentukan masa depan bangsa di masa mendatang (Fida dan Maya, 2012). Data menurut Kementerian Pemberdayaan Perempuan dan Perlindungan Anak dan Badan Pusat Stastistik (2012) pada tahun 2011 penduduk Indonesia yang berumur 0-17 tahun mencapai 82,6 juta atau sebesar 33,9 persen dari keseluruhan penduduk. Apabila dilihat dari sudut pandang ketergantungan maka sepertiga dari penduduk Indonesia masih membutuhkan perlindungan baik dari keluarga, masyarakat ataupun negara. Wong, et al. (2009) menjelaskan bahwa anak bukanlah orang dewasa kecil, namun merupakan individu yang khusus dengan pikiran, tubuh, dan kebutuhan yang unik. Kebutuhan yang diharapkan bisa terlaksananya keberlangsungan hidup yang optimal bagianak-anak Indonesia diantaranya adalah diperhatikannya masalah kesehatan.

Pneumonia merupakan pembunuh utama anak dibawah usia lima tahun (Balita) di dunia, lebih banyak dibandingkan dengan penyakit lain seperti AIDS, Malaria dan Campak. Namun, belum banyak perhatian terhadap penyakit ini. Di dunia, dari 9 juta kematian Balita lebih dari 2 juta Balita meninggal setiap tahun akibat pneumonia atau sama dengan 4 Balita meninggal setiap menitnya. Dari lima kematian Balita, satu diantaranya disebabkan pneumonia. . Di Indonesia berdasarkan hasil Riset Kesehatan Dasar (Riskesdas) tahun 2018, peneumonia merupakan penyebab tertinggi kematian pada bayi dibawah lima tahun maupun bayi baru lahir, menunjukkan; prevalensi nasional pneumonia naik dari $1,6 \%$ pada tahun 2013 menjadi 2\% populasi balita di Indonesia (Riskesdas 2018). Berdasarkan hasil Surkesenas pada tahun 2001, di Indonesia angka kematian bayi sebesar 50 per 1000 kelahiran hidup sedangkan angka kematian balita sebesar 64 per 1000 kelahiran hidup. Hal ini yang menyebabkan WHO merekomendasikan untuk melaksanakan program MTBS yang diadaptasikan sesuai dengan permasalahan Kesehatan bayi dan balita di Indonesia (Munthe, Mahmulsyah, \& Kuntjoro, 2006).

Managemen Terpadu Balita sakit (MTBS) adalah suatu pendekatan keterpaduan dalam tata laksana balita sakit yang dating berobat ke fasilitas rawat jalan pelayanan Kesehatan dasar yang meliputi upaya kuratif terhadap penyakit pneumonia, diare, campak, malaria, infeksitelinga, malnutrisi dan upayapromotif dan preventif diantaranya imunisasi dan pemberian vitamin A, serta konseling pemberian makan. Tujuan utama tata laksana ini untuk menurunkan angka kematian bayi dan anak balita dan menekan morbiditas karena penyakit tersebut (Kemenkes RI, 2014)

Penerapan Manajemen Terpadu Balita Sakit (MTBS) diharapkan tenaga Kesehatan dibekali cara untuk mengenali 
secara dini dan cepat semua gejala anak sakit sehingga dapat ditentukan apakah anak sakit ringan berat dan perlu rujukan. Jika penyakitnya tidak parah petugas dapat memberikan pengobatan/tindakan sesuai pedoman MTBS dan diuraikan juga tentang konseling dan tindak lanjut. Pemenuhan afeksi, kognisi dan moral untuk mengembangkan kemampuan dan ketrampilan intelektual, emosional, dan sosial (Ekowarni, 2015).

Dalam penatalaksanaan balita dengan pneumonia dengan berbasis MTBS, Ibu memerlukan pengetahuan dan kemampuan yang baik dan benar.

Pengetahuan merupakan salah satuvariabel yang mempengaruhi perilaku dan keyakinan seseorang, selain itu kemampuan kognitif membentuk cara berfikir seseorang, meliputi kemampuan untuk mengerti faktor-faktor yang berpengaruh dalam kondisi sakit dan praktek kesehatan personal. Semakin tinggi pengetahuan seseorang tentang arti kesehatan dan manfaat dari fasilitas Kesehatan maka akan semakin besar pula keinginan untuk fasilitas kesehatan (Perry dan Potter, 2010).

Faktor-faktor yang mempengaruhi pengetahuan adalah pendidikan, pekerjaan, usia, minat, pengalaman, dan kebudayaan lingkungan seseorang (Notoatmodjo, 2014).

\section{B. METODE}

Rancangan penelitian yang digunakan dalam penelitian ini adalah Quasi Experimental Design dengan jenis rancangan Pretest Posttest Non Equivalent Without Control Group Design. Menurut Dharma (2011) penelitian quasi experiment adalah penelitian yang dilakukan untuk uji coba suatu intervensi pada kelompok subyek tertentu dengan atau tanpa kelompok pembanding tetapi tidak dilakukan pengacakan dalam memasukkan subyek kedalam kelompok intervensi maupun kelompok kontrol. Dan memilih jenis rancangan Pretest Posttest Non Equivalent Without Control Group Design karena tidak dilakukan pengacakan pada pemilihan kelompok intervensi.

Penelitian ini menggunakan Teknik sampel Total Sampling yaitu peneliti mengambil seluruh anggota sampel yang ada. Pengambilan sampel dalam penelitian ini dilakukan pada ibu - ibu yang memiliki balita yang memenuhi kriteria sampel. sampel yang diambil sebesar 30 ibu. Penelitian ini dilakukan di Puskesmas wilayah Cilacap Selatan I Desa Tambakreja Kecamatan Cilacap Selatan pada bulan Juli - Agustus 2018. Sampel dalam penelitian ini adalah mereka yang telah memenuhi kriteria restriksi, yang terdiri dari kriteria inklusi. Kriteria inklusi yang digunakan dalam penelitian ini adalah sebagai berikut : Ibu yang memiliki balita, bisa baca tulis, ibu mempunyai balita yang pernah mengalami batuk baik batuk bukan pneumonia maupun pneumonia, bersedia menjadi responden.

\section{HASIL}

\section{Analisis Univariat}

a. Distribusi

Karakteristik Responden

1) Usia

Rata-rata usia responden berada pada usia 30,57. (Tabel 1)

2) Pendidikan

Distribusi Pendidikan responden Sebagian besar adalah Pendidikan Dasar (SDSMP) sebanyak 18 responden 
(60\%). (Tabel 2)

b. Pretest Tingkat Pengetahuan Ibu

Ibu sebelum diberikan

Pendidikan Kesehatan tentang

Pneumonia dengan berbasis

MTBS mempunyai tingkat pengetahuan Kategori Baik sebanyak 10 (33,3\%), Kategori Cukup sebanyak 13 (43,4\%) dan kategori Kurang Sebesar 7 (23,3\% ). (Tabel 3)

c. Posttest Tingkat Pengetahuan Ibu

$\begin{array}{ccr}\text { Ibu } & \text { setelah } & \text { diberikan } \\ \text { Pendidikan } & \text { Kesehatan } & \text { tentang } \\ \text { Pneumonia } & \text { dengan } & \text { Berbasis } \\ \text { MTBS } & \text { mempunyai } & \text { tingkat }\end{array}$
pengetahuan dengan kategori Baik sebanyak $20(66,7 \%)$ dan kategori Cukup sebanyak $10 \quad(33,3 \%)$. (Tabel 4)

\section{AnalisisBivariat}

Hasil uji Wilcoxon dengan nilai $\mathrm{Pv}=$ $0,01<0,05$, secara statistic terdapat perbedaan pengetahuan yang bermakna sebelum Pendidikan Kesehatan dengan sesudah dilakukan Pendidikan kesehatan. Tingkat pengetahuan sebelum dilakukan Pendidikan Kesehatan sebanyak $10 \quad(33,3 \%)$ sedangkan tingkat pengetahuan sesudah dilakukan Pendidikan Kesehatan sebanyak $20 \quad(66,7 \%)$. (Tabel 5)

\section{PEMBAHASAN}

\section{AnalisisUnivariat}

a. Tingkat Pengetahuan Ibu Sebelum dilakukan Pendidikan Kesehatan. (Tabel 3).

Berdasarkan hasil penelitian didapatkan data bahwa Ibu sebelum diberikan Pendidikan Kesehatan tentang Penatalaksanaan Pneumonia dengan Pendekatan MTBS mempunyai tingkat pengetahuan Kategori Baik sebanyak 10 (33,3\%), Kategori Cukup sebanyak 13 (43,4\%) dan kategori Kurang Sebesar 7 (23,3\%). Hal ini menunjukkan bahwa tingkat pengetahuan ibu belum sepenuhnya baik, hal ini terjadi bisa diakibatkan karena sosialisasi terkait penatalaksanaan pneumonia belum terserap dengan baik.

b. Tingkat Pengetahuan Ibu Setelah dilakukan Pendidikan Kesehatan. (Tabel 4)

Berdasarkan hasil penelitian didapatkan data bahwa Ibu setelah diberikan Pendidikan Kesehatan tentang Pneumonia Berbasis MTBS mempunyai tingkat pengetahuan dengan kategori Baik sebanyak 20 $(66,7 \%)$ dan kategori Cukup sebanyak $10(33,3 \%)$.

Pengetahuan adalah hasil dari tahu dan terjadi setelah orang melakukan pengindraan terhadap objek. Pengetahuan merupakan hal yang dominan dalam membentuk tindakan seseorang (Notoatmodjo, 2014)

Menurut Notoatmodjo (2014) pengetahuan adalah atau kognitif merupakan domain yang sangat penting dalam membentuk suatu tindakan seseorang.

\section{Analisis Bivariate (Tabel 5)}

Berdasarkan hasil penelitian didapatkan hasil terdapat pengaruh yang signifikan Pendidikan Kesehatan 
tentang Pneumonia terhadap pengetahuan ibu dengan pv $0,01<0,05$. Tingkat pengetahuan sebelum dilakukan Pendidikan Kesehatan sebanyak $10 \quad(33,3 \%)$ sedangkan tingkat pengetahuan sesudah dilakukan Pendidikan Kesehatan sebanyak 20 $(66,7 \%)$.

Pengetahuan merupakan hasil dari tahu, dan terjadi setelah orang melakukan pengindraan terhadap suatu obyek tertentu. Penginderaan terjadi melalui panca indra manusia, yaitu indra penglihatan, indra pendengaran, indra penciuman, indra perasa, dan indra peraba. Namun Sebagian besar pengetahuan manusia didapatkan dari indra penglihatan dan indra pendengaran. Pengetahuan juga merupakan domain yang sangat penting untuk terbentuknya tindakan seseorang, karena dengan pengalaman akan lebih langgeng daripada yang tidak didasari oleh pengetahuan (Noto Atmodjo, 2010).

Hal ini sesuai dengan hasil penelitian ini bahwa setelah dilakukan tindakan Pendidikan Kesehatan tentang pneumonia dengan pendekatan MTBS maka tingkat pengetahuan meningkat. Hal ini didukung dengan karakteristik responden dengan usia yang tergolong dalam dewasa muda. Sehingga tingkat kematangan berfikir responden sudah matang juga. Hasil karakteristik penelitian menunjukkan usia ibu yang termuda usia 21 tahun dan tertua usia 39 tahun, serta rata-rata usia ibu berada pada kategori dewasa awal yaitu 30,57 tahun. Usia ibu juga salah satu factor yang mempengaruhi tingkat pengetahuan ibu (Notoatmodjo, 2014). Semakin cukup umur tingkat kematangan dan kekuatan seseorang akan lebih matang dalam berpikir dan bekerja dari segi kepercayaan masyarakat yang lebih dewasa akan lebih percaya dari pada orang yang belum cukup tinggi kedewasaannya. Hal ini sebagai akibat dari pengalaman jiwa (Nursalam, 2011).

\section{E. KESIMPULAN DAN SARAN}

1. Kesimpulan

Hasil penelitian ini terdapat pengaruh yang signifikan Pendidikan Kesehatan tentang penatalaksanaan Pneumonia berbasis MTBS terhadap pengetahuan ibu dengan pv $0,01<0,05$. Tingkat pengetahuan sebelum dilakukan Pendidikan Kesehatan sebanyak $10 \quad(33,3 \%)$ sedangkan tingkat pengetahuan sesudah dilakukan Pendidikan Kesehatan sebanyak 20 $(66,7 \%)$.

2. Saran

Untuk penelitian selanjutnya bisa dilakukan penelitian tentang ketercapaian pelaksanaan MTBS di wilayah puskesmas oleh tenaga Kesehatan maupun kader, sehingga program bisa berkesinambungan mengingat tingkat pengetahuan ibu sudah dalam tingkat baik.

\section{DAFTAR PUSTAKA}

Dharma, K. K. (2011). Metodologi penelitian keperawatan: Panduan melaksanakan dan menerapkan hasil penelitian. Jakarta: CV. Trans Info Media.

Dinas Kesehatan Kabupaten Cilacap, PSG 2016 Hasil Pemantauan Status Gizi Balita (PSG) :Cilacap 
Dinas Kesehatan Kabupaten Cilacap, 2012, Profil Kesehatan Kabupaten Cilacap.

Djamil, M. N. 2013. Anak Bukan untuk di Hukum. Sinar Grafika. Semarang.

Ekowarni, E. 2015. Pola Perilaku Sehat dan Model Pelayanan Kesehatan Remaja. Jurnal Psikologi. 28(2) 97104.

https://doi.org/10.22146/jpsi.7683

Fida dan Maya. 2012. Pengantar Ilmu Kesehatan Anak. D Medika. Yogyakarta.

Kementerian Kesehatan RI, 2013, Badan Penelitian dan Pengembangan Kesehatan (Balitbang) Riset Kesehatan Dasar (Riskesdes) 2012, Laporan Nasional Balitbang, Jakarta

Kementerian Kesehatan RI, 2010, Badan Penelitian dan Pengembangan Kesehatan (Balitbang) Riset Kesehatan Dasar (Riskesdes) 2010, Laporan Nasional Balitbang, Jakarta

Munthe, Mahmulsyah \& Kuntjoro, T, 2006. Strategi Perbaikan Mutu Pelayanan Manajemen Terpadu Balita Sakit (MTBS) di Puskesmas Rantau Panjang Kabupaten Merangin-Jambi. Thesis. Universitas Gajah Mada Yogyakarta.

Notoatmodjo, S. 2014. Metodologi Penelitian Kesehatan, edisi revisi. Jakarta: Rineka Cipta
Notoatmodjo, S. 2014. Ilmu Perilaku Kesehatan. Jakarta : Rineka Cipta

Nursalam, 2011. Profil Penduduk Lanjut Usia 2009. Jakarta

Departemen Kesehatan RI 2008, Profil Kesehatan Indonesia 2008. $<$ http://www.depkes.go.id $>$ di akses 27 Mei 2015

Mubarok, I, dkk. 2007. Promosi Kesehatan Sebuah Pengantar Proses Belajar Mengajar Dalam Pendidikan. Graha Ilmu:Yogyakarta

Notoatmodjo, S. 2007. Promosi Kesehatan dan Ilmu Perilaku. Jakarta : Rineka Cipta

Notoatmodjo, S. 2010. Promosi Kesehatan Teori dan Aplikasinya. Cetakan 2. Jakarta : Rineka Cipta.

Perry \& Potter. 2010. Fundamental of Nursing. Consep, Process, and Practice. Edisi 7 bol 3. Jakarta: EGC.

Setiawati. S. 2008. Proses Pembelajaran dalam Pendidikan Kesehatan. TIM: Jakarta

WHO. 2009. Buku Saku Pelayanan Kesehatan Anak di RumahSakit. Depkes :Jakarta.

Wong et al. 2009. Buku Ajar Keperawatan Pediatrik. Alih bahasa Hartono, A dkk. Jakarta : EGC

\section{LAMPIRAN}


Tabel 1

Distribusi Karakteristik Usia Responden

\begin{tabular}{lllll}
\hline Karakteristik & Mean & Median & Min-Maks & Stand.deviasi \\
\hline Usia (Tahun) & $\mathbf{3 0 , 5 7}$ & $\mathbf{3 0}$ & $\mathbf{2 1 - 3 9}$ & $\mathbf{5 , 4 5 6}$ \\
\hline
\end{tabular}

Tabel 2

Distribusi Karakteristik Responden Menurut Pendidikan

\begin{tabular}{ccc}
\hline $\begin{array}{c}\text { Karakteristik } \\
\text { Pendidikan }\end{array}$ & Frekuensi & Prosentase (\%) \\
\hline Dasar (SD-SMP) & 18 & 60 \\
Menengah (SMA) & 11 & 36,7 \\
Tinggi (PT) & 1 & 3,3 \\
\hline
\end{tabular}

Tabel 3

Distribusi Frekuensi Tingkat Pengetahuan Ibu Sebelum dilakukan Pendidikan Kesehatan tentang Penatalaksanaan Pneumonia dengan Pendekatan MTBS di Puskesmas Cilacap Selatan 1

\begin{tabular}{llcc}
\hline No. & Tingkat Pengetahuan Ibu & Frekuensi & Prosentase (\%) \\
\hline 1 & Baik & 10 & 33.3 \\
\hline 2 & Cukup & 13 & 43.4 \\
\hline 3 & Kurang & 7 & 23.3 \\
\hline Jumlah & 30 & 100 \\
\hline
\end{tabular}

Tabel 4

Distribusi Frekuensi Tingkat Pengetahuan Ibu Setelah dilakukan Pendidikan Kesehatan tentang Penatalaksanaan Pneumonia dengan Pendekatan MTBS di Puskesmas Cilacap Selatan 1

\begin{tabular}{llcc}
\hline No. & Tingkat Pengetahuan Ibu & Frekuensi & Persentase (\%) \\
\hline 1 & Baik & 20 & 66.7 \\
\hline 2 & Cukup & 10 & 33.3 \\
\hline Jumlah & 30 & 100 \\
\hline
\end{tabular}


Tabel 5

Pengaruh Pendidikan Kesehatan terhadap Tingkat Pengetahuan Sebelum dan Sesudah diberikan Intervensi

\begin{tabular}{|c|c|c|c|c|c|c|c|c|}
\hline \multirow{3}{*}{ Kelompok } & \multicolumn{6}{|c|}{ Tingkat Pengetahuan } & \multirow{2}{*}{\multicolumn{2}{|c|}{ Jumlah }} \\
\hline & \multicolumn{2}{|c|}{ Baik } & \multicolumn{2}{|c|}{ Cukup } & \multicolumn{2}{|c|}{ Kurang } & & \\
\hline & $\mathbf{n}$ & $\%$ & $\mathbf{n}$ & $\%$ & $\mathbf{n}$ & $\%$ & $\mathbf{N}$ & $\%$ \\
\hline $\begin{array}{l}\text { Sebelum } \\
\text { diberikan } \\
\text { Penkes }\end{array}$ & 10 & 33,3 & 13 & 43,4 & 7 & 23,3 & 30 & 100 \\
\hline $\begin{array}{l}\text { Sesudah } \\
\text { diberikan } \\
\text { Penkes } \\
\end{array}$ & 20 & 66,7 & 10 & 33,3 & $\mathbf{0}$ & $\mathbf{0}$ & 30 & 100 \\
\hline$Z=-3,314$ & & & & & &, 01 & & \\
\hline
\end{tabular}

